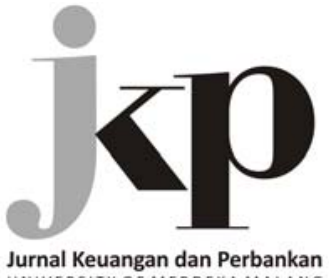

UNIVERSITY OF MERDEKA MALANG
Article history:

Received: 2018-08-19

Revised: 2018-09-23

Accepted: 2018-10-15

\author{
Abdul Ghofar ${ }^{1}$, Farisan Noviandry ${ }^{2}$ \\ ${ }^{1}$ Department of Accounting, \\ Faculty of Economics and \\ Business, Universitas Brawijaya \\ Jl. M.T. Haryono No.165 Malang, \\ 65145 , Indonesia \\ ${ }^{2}$ PT Krakatau Industrial Estate \\ JI. K.H. Yasin Beji No. 6, Cilegon, \\ 42435, Indonesia
}

$\triangle$ Corresponding Author:

Abdul Ghofar:

Tel +62 341551396

E-mail: ghofar@ub.ac.id

This is an open access

article under the CC-BY-SA license

\author{
Abdul Ghofar (Indonesia), Farisan Noviandry (Indonesia) \\ Foreign Ownership, Corporate Governance \\ Mechanism and Technical Efficiency of Indonesia \\ Banking Industry
}

\begin{abstract}
A large number of commercial banks in Indonesia are considered not ideal for the future of Indonesian banking because most of these banks are considered unhealthy and inefficient. This research aimed to examine the input and output efficiency in the Indonesian banking industry and the influence of foreign ownership and corporate governance mechanisms measured by the size of the board of commissioners and the percentage of the independent commissioner on technical efficiency using a non-parametric approach of Data Envelopment Analysis (DEA). This research used 50 foreign exchange commercial banks of Indonesia from 2012 2014. The results of DEA indicated that the efficiency of foreign exchange commercial banks has increased significantly during the observation period. Other results showed that banks with foreign ownership had a strong and positive link with technical efficiency. In line with the established literature on emerging markets, foreign ownership banks appear to be more efficient than banks with fully domestic ownership. However, the board of commissioner size showed no effect on banks technical efficiency. The percentage of independent commissioner showed a negative effect on efficiency that consistent with the argument that tighter monitoring of board of commissioners might impede performance.
\end{abstract}

Keywords: Corporate Governance; Data Envelopment Analysis; Foreign Ownership; Technical Efficiency; Tobit Model

JEL Clasification: D61, G35, M41

Citation: Ghofar, A., \& Noviandry, F. (2018). Foreign ownership, corporate governance mechanism and technical efficiency of Indonesia banking industry. Jurnal Keuangan dan Perbankan, 22(4), 734-746. https://doi.org/10.26905/ jkdp.v22i4.2461

\begin{abstract}
Abstrak
Sejumlah besar bank komersial di Indonesia dianggap tidak ideal untuk masa depan perbankan Indonesia karena sebagian besar bank-bank ini dianggap tidak sehat dan tidak efisien. Penelitian ini bertujuan untuk menguji efisiensi input dan output dalam industri perbankan Indonesia dan pengaruh kepemilikan asing dan mekanisme corporate governance diukur dengan ukuran dewan komisaris dan prosentase komisaris independen pada efisiensi teknis dengan menggunakan pendekatan non-parametrik Data Envelopment Analysis (DEA). Penelitian ini mengounakan 50 bank umum devisa Indonesia sebagai sampel penelitian untuk periode 2012-2014. Hasil DEA menunjukkan bahwa efisiensi bank devisa telah meningkat secara signifikan selama periode observasi. Hasil lain menunjukkan bahwa bank dengan kepemilikan asing memiliki hubungan yang kuat dan positif dengan efisiensi teknis. Sejalan dengan literatur yang mapan di pasar negara berkembang, bank yang mempunyai kepemilikan asing terbukti lebih efisien daripada bank dengan kepemilikan domestik secara penuh. Namun, ukuran dewan komisaris tidak menunjukkan efek pada efisiensi teknis bank. Persentase komisaris independen menunjukkan efek negatif pada efisiensi yang konsisten dengan argumen bahwa pemantauan ketat oleh dewan komisaris dapat menghambat kinerja perusahaan.
\end{abstract}

Kata Kunci: Tata Kelola Perusahaan; Data Envelopment Analysis; Kepemilikan Asing; Efisiensi Teknis; Tobit Model 


\section{Foreign Ownership, Corporate Governance Mechanism and Technical Efficiency of Indonesia Banking Industry Abdul Ghofar \& Farisan Noviandry}

Banks are financial institutions which hold strategic functions in advancing the economic growth of a country. One of these functions is as an intermediary institution that acts as a channeled of funds from the surplus sector unit that stores excess funds in banks with a deficit unit sector by borrowing funds to banks (Song \& Thakor, 2015).

The Indonesian banking sector is a big industry which has shown a rapid development. There has been an increase of 3 percent for Return of Asset (ROA) and an increase of 88 percent for total assets and lending in 2014 (www.bi.go.id, 2014), considered as a rapid and large figure increase. The number of commercial banks to date in Indonesia has reached 120 commercial banks and 1,643 rural banks. A large number of commercial banks in Indonesia is considered not ideal for the future of Indonesian banking because most of these banks are considered unhealthy and inefficient. This condition makes the banking industry in Indonesia is unable to compete with foreign-owned banks in Indonesia. To overcome this problem, the Financial Services Authority (2015) formulated the Indonesian Financial Services Masterplan or Master Plan Sektor Jasa Keuangan Indonesia (MPJKI) which aims to streamline the number of banks in Indonesia by 50 percent in the next ten years (www.ojk.go.id, 2015). This streamlining effort was carried out by mergers and acquisitions of banks which were deemed inefficient. Moreover, an existing alteration of rapid and large financial structure needs an assessment of costs and income efficiency (Berger \& Mester, 1997). This is due to the increase in asset value or large credit disbursement which is not necessarily able to present good efficiency.

Previously, the assessments of banking efficiency in Indonesia have often been carried out, and one of the approaches commonly used is the ratio of Operational Expenses to Operating Incomes (BOPO). BOPO ratio is measured by comparing operating expenses with operating income. The smaller the $\mathrm{BOPO}$ value is, the better a bank is in managing its operational costs; therefore, the less likely the bank will experience financial problems.

Efficiency measurement with BOPO ratio has several weaknesses, namely financial ratios only comparing one variable to another, so that it cannot accommodate inputs and outputs which have more than one variable to measure efficiency (Hoque \& Rayhan, 2012). Moreover, banks as intermediary institutions use a lot of inputs and outputs in their operational processes (Jamali et al., 2015). In addition, measuring efficiency by using ratios also cannot directly compare the efficiency of a bank with other banks (Song \& Thakor, 2015).

Because the calculation of the BOPO ratio has many shortcomings, it is necessary to use other measurement methods to measure banking efficiency. Bruce (2011) explains that there are two approaches to assessing the level of efficiency using parametric and non-parametric methods. The parametric approach includes the Stochastic Frontier Approach (SFA), Distribution-Free Approach (DFA), and Thick Frontier Approach (TFA), while non-parametric uses Data Envelopment Analysis (DEA). Of the two approaches, the non-parametric approach using DEA has advantages which other approaches do not have, not requiring the assumption of the form of production functions in forming Frontier production; hence, errors in the specification of production functions can be eliminated (Chen, 2005; Hoque \& Rayhan, 2012). Moreover, this method is also sensitive to input-output variables used in measurement, so that management can find out the part of input or output variables which need to be considered to increase bank efficiency (Sathye, 2003). In addition, the DEA can help find causes and solutions to inefficiencies which will add relative benefits to the use of this method (Epstein \& Henderson, 1989).

So far it is known that efficiency assessments have a strong relationship with bank-specific conditions (Wang et al., 2014). The bank's specific conditions are factors originating from the bank's in- 
ternal portrayals in the year-end report (Song \& Thakor, 2015). Some previous studies have found bank-specific conditions which affect bank efficiency as measured by the DEA method. These factors include total assets (Delis \& Papanikolu, 2009; Sufian \& Noor, 2009; Sufian \& Habibullah, 2010; Wang et al., 2014), capital adequacy ratio (Muazaroh et al., 2012), ROA (Sufian \& Noor, 2009; Sufian \& Habibullah, 2010), and non-performing loans (Sufian \& Habibullah, 2010; Wang et al., 2014). However, the influence of the corporate governance mechanism has not been a concern of previous research. Meanwhile, the mechanism of corporate governance itself becomes one of the important factors in managing efficiency (Mueller, 2006; Drake, Myers, \& Myers, 2009).

The implementation of a good corporate governance (GCG) mechanism is expected to protect company owners in the form of supervision of management regarding resource efficiency management (Mueller, 2006; Drake, Myers, \& Myers, 2009; Ward, Brown, \& Rodriguez, 2009). The placement of the board of commissioners is expected to reduce agency problems, provide supervision and reduce the concerns of shareholders regarding the waste of resources and inefficiencies that occur. In addition, the size of the board of commissioners themselves influences the effectiveness of the supervisory function (Carcello \& Neal, 2000; Chen, 2005). Based on the description above, the board of commissioners can indeed provide benefits related to efficiency.

In addition, independent commissioners are also one of the positions, which are expected to carry out the supervisory function in order to create good corporate governance (Lefort \& Urzua, 2008). Holod \& Lewis (2011) explained that an increased proportion of independent commissioners would have an impact on company value and company performance. In addition, independent commissioners are an effective choice in minimizing the risk of opportunistic behavior from management (Ghofar \& Islam, 2015).
In order for the corporate governance mechanism to properly work, the ownership structure factor must not be neglected because the owner plays an important role in determining the company such as the direction of business development, corporate culture, professional policy, control and corporate governance (Colley et al., 2003) Furthermore, the ownership structure has a strong influence on the mechanism of Corporate Governance related to control and supervision (Lu et al., 2012). The ownership structure by foreign parties is assumed to have a big role in increasing bank efficiency. Foreign institutions can operate more efficiently than local institutions because they have superior managerial expertise, best-practice procedures and policies in their fields (Genay et al., 2000).

This study is aimed at analyzing the level of banking efficiency in Indonesia using DEA approach and examining the influence of three important corporate governance mechanism factors namely the size of board commissioners and independent commissioners, and foreign capital ownership on the technical efficiency of banking in Indonesia in 20122014. The results of the study show that banks with foreign ownership are more efficient compared to that of fully domestic-owned banks. It is also found that the size of the board of commissioners does not affect efficiency and the percentage of independent commissioners has a negative impact on the bank's efficiency. The study contributes to extending the literature in regard to research on banking and corporate governance in two ways. First, as previous research undermines the relationship between technical efficiency and corporate governance mechanisms, this study fills the gap by providing evidence that ownership structure measured by foreign ownership has a positive link with technical efficiency of banks. It is also known that the board of commissioner characteristics either size and independence do not contribute to improving the efficiency of banks. Most previous studies stress the role of corporate governance mechanisms to monitor management, without extending the function to 


\section{Foreign Ownership, Corporate Governance Mechanism and Technical Efficiency of Indonesia Banking Industry Abdul Ghofar \& Farisan Noviandry}

improving efficiency. Second, as in 2015 Indonesia and other South East Asian countries (ASEAN) start to implement ASEAN community by which the mobility of funds is freed, the study may contribute to providing an insight that mobility of funds through ownership may improve bank's efficiency. The paper is structured as follows. In Section 2, literature review and hypotheses development are presented. Section 3 discusses the research method; while Section 4 presents the results and Section 5 presents the discussions. The conclusion, implication, suggestion and limitations are presented in Section 6.

\section{HYPOTHESES DEVELOPMENT}

Efficiency can be defined as the ratio between the number of outputs and inputs. Efficiency is one of the performance parameters, which theoretically underlies the entire performance of an organization by referring to the philosophy of the ability to produce optimal output with its existing input is an expected measure of performance. Thus, there is a separation between price and unit used (input) and price and unit produced (output). The concept of efficiency was first introduced by Farrell (1957). The concept of measuring efficiency according to Farrell (1957) must be able to calculate multiple inputs (compound). Moreover, the efficiency itself can be classified into technical efficiency and allocative efficiency.

Technical efficiency describes the relationship between inputs and outputs in a production process. In other words, technical efficiency shows the company's ability to reach the maximum possible output from some inputs. Meanwhile, allocative efficiency shows the ability of companies to use inputs with the optimum proportion at the level of certain input prices. These two components are then combined to produce a measure of total efficiency or economic efficiency. Kumbhaker \& Lovell (2000) argued that technical efficiency was one of the components of overall economic efficiency. However, in order to achieve economic efficiency, a company must be technically efficient. To achieve the maximum level of profit, a company must be able to produce at an optimal level of output with a certain number of inputs (technical efficiency) and produce outputs with the right combination at a certain price level (allocative efficiency).

Foreign bank ownership can have a positive impact on bank efficiency because foreign ownership can bring more advanced risk management, a better corporate governance culture, and create a competitive climate which demands domestic banks to increase efficiency (Genay et al., 2000). In addition, according to Claessens, Demirgüç-Kunt, \& Huizinga (2001), foreign banks are often associated with better and more superior management and technology practices from local banks. Thus, bank ownership by foreign parties is allegedly able to increase bank efficiency. Based on these considerations, a hypothesis can be formulated:

$\mathrm{H}_{1}$ : bank ownership by foreign parties has a positive effect on the level of banking technical efficiency

The board of commissioners is appointed by the shareholder as the supervisor of management performance, the appointment of the board of commissioners is due to the emergence of agency problems such as information asymmetry between the principal and the agent as explained in the agency theory (Jamali et al., 2015). With the increasing size of the board of commissioners, it will provide benefits such as increasing the supervisory function of commissioners towards management and can reduce management consumption which can lead to waste of resources (Kiel \& Nicholson, 2003). Moreover, the addition of commissioners can increase knowledge and expertise which can be useful for decision making in order to create efficient company performance (Larmou \& Vafeas, 2010). However, the large size of the board of commissioners can provide problems which include the increasing size of the board of directors leading to increased Agency Cost 
(Ghofar \& Islam, 2015), larger board of commissioners can also create coordination and communication problems resulting in poor performance (Lipton \& Lorsch, 1992; Jensen, 2010). In addition, the oversized board of commissioners can cause the board members to rely on other members related to the execution of duties (Jensen, 2010; Yunos, 2011). Based on these considerations, a hypothesis can be formulated:

$\mathrm{H}_{2}$ : the size of the board of directors has a negative effect on the level of banking technical efficiency

The existence of an independent commissioner is considered to be able to provide good oversight of the management performance efficiency, and the supervision carried out will increase the size of the independent commissioner. The larger the size of independent commissioners, there will be better advice which they also represent minority shareholders (Ghofar \& Islam, 2015). In addition, independent commissioners are the best position to carry out the monitoring function to create a company which has GCG or good corporate governance. Lefort \& Urzua (2007) found that an increase in the proportion of independent commissioners had an impact on company value and performance. In addition, Kiel \& Nicholson (2003) argued that independent commissioners in an institution are effective choices in minimizing the risk of opportunistic behavior from management. In other words, the composition of independent commissioners in the bank is expected to have a positive effect on bank efficiency. Based on these considerations, a hypothesis can be formulated:

$\mathrm{H}_{3}$ : the size of independent commissioners has a positive effect on the level of banking technical efficiency

\section{METHODS}

This research is a quantitative study. In this research, the sampling technique used is purposive sampling. The criteria used as the basis for sample selection are: (1) bank which operated in Indonesia and obtained a license to run its business as a foreign exchange bank in the period of 2012-2014 and; (2) bank issues financial statements for the period of 2012-2014. The study uses foreign exchange banks as samples since they have a more extended function which is conducting foreign exchange transaction compared to non-foreign exchange banks. Moreover, foreign exchange banks have more possibility to have foreign ownership which is one of the focuses of the study. The samples are generated as follows: (1) total banks - 120; (2) non-foreign exchange banks - 70; and (3) total samples - 50 . Hence the number of samples is 50 banks. As the observation period is 3 years, the number of observation is 150 .

The data are collected from the banks' financial statements from 2012-2014, and financial ratio data obtained from the company's annual report. The annual report and the bank's financial statements are obtained from the official website of the Financial Services Authority (www.ojk.go.id), the website of the sample banks, and the Osiris-Bureau van Dijk Database. The data in the annual report are used to determine the input and output variables for the measurement of the technical efficiency of banking, bank ownership by foreign parties and the mechanism of corporate governance proxied by the size of the board of commissioners and the size of independent commissioners.

The dependent variable in this study is the level of technical banking efficiency measured by using DEA. The technical efficiency is obtained using the assumption of variable return to scale (VRS). The assumption of VRS is used because of differences in bank size, financial markets which have not fully developed, and imperfect competition in a country resulting in the assumption that banks operate on an optimal scale is irrelevant (Williams \& Nguyen, 2005; Wang et al., 2014). This study utilizes the input orientation as an approach to measure efficiency. 


\section{Foreign Ownership, Corporate Governance Mechanism and Technical Efficiency of Indonesia Banking Industry Abdul Ghofar \& Farisan Noviandry}

The input variable consists of three inputs and two outputs. The variables refer to the research model presented by Gardener, Molyneux, \& Nguyen-Linh (2011) which includes: (1) input; total deposits, including deposits, savings, time deposits, certificates of deposit, and deposits from other banks found on the balance sheet until the end of the year of one bank; personnel expenses, covering salary and bonus expenses. This variable is found in the bank's income statement; and paid-up capital (MDS), the capital deposited by the owners; and (2) output; total loans/financing, the amount of credit or financing provided by the bank found in the balance sheet until the end of the year of one bank; and net income, the total profit for the current year in the income statement until the end of the year of one bank.

The value of technical efficiency measured using DEA is between 0 and 1 . The sample of banks which has a value of 1 is considered an efficient bank, while the sample which has an efficiency value less than 1 is considered as a less efficient bank.

This study employs three independent variables, bank ownership by foreign parties, the corporate governance mechanism proxied for the size of the board of commissioners and the size of the independent commissioner. This are the explanations: (1) bank ownership by foreign parties; this study measures bank ownership by foreign parties using dummy variables. Banks whose controlling shareholders are owned by foreign parties are given a value of 1 ; meanwhile, others are given a value of 0 ; (2) size of the board of commissioners; the valuation of this variable is assessed by the total number of commissioners; and (3) size of independent commissioners; the valuation of this variable is assessed by the percentage of the number of independent commissioners.

The use of control variables is based on previous research employing the same variables. The control variables used in this study are as follows: (1) go public status (GOPUBLIC); this study mea- sures the status of banks whose shares have been listed on the Indonesia Stock Exchange (IDX) using dummy variables. Banks whose shares are listed in the IDX are given a value of 1 , while those nonlisted are given a value of 0 ; (2) non-performing loan (NPL); according to Berger \& DeYoung (1997), NPL are the values of credit loan which have reached 90days overdue or whose interest is no longer increased, which is then divided by the total loan value; and (3) bank size (SIZE); the size of the bank shows the extent of the bank's operational activities. In this study, the bank size is measured by the $\log$ of total assets (Suryanto, 2016)

Data are taken from 50 Indonesian foreign exchange banks for three-year period (2012-2014). Data analysis methods regarding the factors which influence the level of efficiency are first obtained from the first stage using the DEA method; afterward, the efficiency value will be analyzed with several environmental variables to determine the relationship and the nature of the relationship between these variables to the second stage. Hence, these two stages in this study are called the TwoStage Data Envelopment Analysis. Meanwhile, in analyzing the factors influencing the level of efficiency the Tobit model is employed as follows:

$$
\begin{aligned}
\text { EFF }= & \alpha+\beta_{1} \text { FOREIGN }+\beta_{2} \text { SUPVBOARD }+\beta_{3} \text { KI } \\
& +\beta_{4} \text { GOPUBLIC }+\beta_{5} N P L+\beta_{6} \text { SIZE }+e
\end{aligned}
$$

Where:

$\begin{array}{ll}\text { EFF } & : \text { technical efficiency } \\ \alpha & : \text { constant } \\ \text { FOREIGN } & : \text { bank ownership by foreign } \\ \text { SUPVNOARD } & : \text { size of the board of commission- } \\ & \text { ers } \\ \text { KI } & : \text { board of independent commis- } \\ & \text { sioners } \\ \text { GOPUBLIC } & : \text { go public status } \\ \text { NPL } & : \text { non-performing loans } \\ \text { SIZE } & : \text { log total assets }\end{array}$


e

$\beta_{1}-\beta_{6} \quad:$ regression coefficient

\section{RESULTS}

Table 1 show the descriptive statistics results. The comparison of efficiency between a bank with foreign ownership and non-foreign ownership is presented in Table 2.
Based on Table 1 and Table 2, it can be seen that the average technical efficiency of banks is 0.77 ; while the average foreign ownership is relatively low which is 33.33 percent. The size of board commissioners is four persons on average with 47 percent of them are independent board members. Interestingly, it can be seen that banks with foreign ownership have higher efficiency value which is 0.858 on average compared to non-foreign ownership banks which have only 0.776 efficiency value.

Table 1. Descriptive Statistics of Variables ( $N=150)$

\begin{tabular}{|c|c|c|c|c|c|}
\hline Variable & $\mathbf{N}$ & Min & Max & Average & Standard Deviation \\
\hline Bank Technical Efficiency & 150 & 0.43 & 1 & 0.77 & 0.16 \\
\hline Bank Ownership by Foreign & 150 & 0 & 1 & $33.33 \%$ & $47.29 \%$ \\
\hline Parties & & & & & \\
\hline $\begin{array}{l}\text { Size of the Board of } \\
\text { Commissioners }\end{array}$ & 150 & 0 & 8 & 4,44 & 1,87 \\
\hline $\begin{array}{l}\text { Board of Independent } \\
\text { Commissioners }\end{array}$ & 150 & 0 & 1 & $47.12 \%$ & $22.44 \%$ \\
\hline Go Public Status & 150 & 0 & 1 & 0.57 & 0.49 \\
\hline Non-Performing Loan & 150 & 0 & $10.36 \%$ & $2.22 \%$ & $1.94 \%$ \\
\hline Bank Size & 150 & 5.9 & 8.81 & 7.26 & 0.65 \\
\hline
\end{tabular}

Table 2. Technical Efficiency Comparison ( $N=150)$

\begin{tabular}{lcccc}
\hline \multicolumn{1}{c}{ Variable } & Observasi & Mean & Median & Mann Whitney P-value \\
\hline $\begin{array}{l}\text { Bank Technical Efficiency of the bank } \\
\text { with foreign ownership }\end{array}$ & 96 & 0.858 & 0.912 & 0.012 \\
$\begin{array}{l}\text { Bank Technical Efficiency of the bank } \\
\text { with no-foreign ownership }\end{array}$ & 54 & 0.776 & 0.761 & \\
\hline
\end{tabular}

Table 3. Banking Efficiency Statistics in Indonesia 2012-2014 Data Envelopment Analysis (DEA) Approach

\begin{tabular}{lrrr}
\hline \multicolumn{1}{c}{ Details } & $\mathbf{2 0 1 2}$ & $\mathbf{2 0 1 3}$ & $\mathbf{2 0 1 4}$ \\
\hline The Number of Banks & 50 & 50 & 50 \\
The Number of Efficient Banks & 12 & 13 & 14 \\
The Number of Inefficient Banks & 38 & 37 & 36 \\
\% of Efficient Banks & $24 \%$ & $26 \%$ & $28 \%$ \\
Average EfficiencyValue & 0.76 & 0.83 & 0.84 \\
Standard Deviation & 0.18 & 0.16 & 0.14 \\
Lowest Bank Efficiency Value & 0.43 & 0.45 & 0.51 \\
Banks with the Lowest Efficiency & Ganesha Bank & Ganesha Bank & Bank Capital Indonesia, Tbk
\end{tabular}




\section{Foreign Ownership, Corporate Governance Mechanism and Technical Efficiency of Indonesia Banking Industry Abdul Ghofar \& Farisan Noviandry}

From non-parametric independent t-test, it can be concluded that the mean of technical efficiency of banks with foreign ownership is significantly different compared to that of banks with no-foreign ownership, as the p-value of Mann Whitney test is less that 0.05 which is 0.012 .

Efficiency assessment in this study utilizes MaxDEA software with a non-parametric DEA approach with the assumption that input-oriented Variable Return to Scale (VRS) will produce bank efficiency scores ranging from 0-1 or 100 pecent. Therefore, the bank is determined to be technically efficient when it has an efficiency score of 1 or 100 percent. On the other hand, the bank is considered inefficient having a score below 1 or 100 percent.

Table 3 show the number of efficient banks from 2012-2014 increasing from 12 banks (24 percent) in 2012 to 13 banks (26 percent) in 2013, followed by another increase to 14 banks (28 percent) in 2014. Increased efficiency trends can also be seen from the average increase in bank efficiency scores in 2012 where the efficiency score was 76 percent to 83 percent in 2013, increasing to 84 percent in 2014.

Table 3 can also show banks which have the lowest efficiency score every year. In 2012 and 2013, the lowest efficiency score was owned by Ganesha bank with an efficiency score of 0.43191 (43 percent) and 0.45286 (45 percent). Whereas in 2014, the lowest efficiency score was recorded by Bank Capital Indonesia, Tbk. with an efficiency score of 0.5145 (51 percent). For these banks to achieve an efficiency score of 1 or 100 percent, the input variables must be reduced. For Ganesha banks in 2012 and 2013, they must reduce their input variables by 57 percent (100 percent -43 percent) and 55 percent (100 percent - 45 percent). Meanwhile, Bank Capital Indonesia, Tbk. in 2014 must reduce its input variables by 49 percent (100 percent - 51 percent).

Inefficient banks can find sources of inefficiency by identifying other banks which are used as benchmarking references on how much output needs to be increased or how much input needs to be reduced to improve efficiency. This study will discuss benchmarking which can be done by banks which are not yet efficient in Indonesia through the identification of input variables and output variables which must be increased or reduced. The results of Data Envelopment Analysis banks which have not been efficient in Indonesia in 2012, 2013, and 2014 are shown in Table 4.

Table 4 shows the value of input and output variables that have a potential improvement for foreign exchange banks in Indonesia for 2012, 2013, and 2014. A positive sign indicates that the bank must increase the variable by the value described to achieve optimal efficiency while the sign negative indicates that the bank must reduce the variable according to the value that has been analyzed by the DEA approach.

In 2012, foreign exchange banks in Indonesia needed an average reduction in the value of inputs such as Total Deposits of IDR5,139,598 (in millions), paid-in capital of IDR411,313 (in millions), and personal expenses of IDR126,393 (in millions). In addition, foreign exchange banks in Indonesia in 2012 also had to increase their output variables such as the total lending of IDR225,082 (in millions) and net income of IDR44,705 (in millions).

Subsequently in 2013, to achieve optimum efficiency, foreign exchange banks in Indonesia still

Table 4. Potential Improvement Variables (in millions of rupiahs)

\begin{tabular}{cccccc}
\hline Year & Total Deposits & Paid-Up Capital & $\begin{array}{c}\text { Personel } \\
\text { Expenses }\end{array}$ & $\begin{array}{c}\text { Total Loans/ } \\
\text { Financing }\end{array}$ & Net Income \\
\hline $\mathbf{2 0 1 2}$ & IDR $(5,139,598)$ & IDR $(411,313)$ & IDR $(126,393)$ & IDR 225,082 & IDR 44,705 \\
$\mathbf{2 0 1 3}$ & IDR $(3,276,989)$ & IDR $(320,055)$ & IDR $(112,762)$ & IDR 133,858 & IDR 182,308 \\
$\mathbf{2 0 1 4}$ & IDR $(3,421,690)$ & IDR $(226,245)$ & IDR $(132,970)$ & IDR - & IDR 66,967 \\
\hline
\end{tabular}


had to reduce the value of inputs such as Total Deposits amounting to IDR3,276,989 (in millions), paidup capital of IDR320,055 (in millions), and personnel expenses in the amount of IDR112,762 (in millions). In addition, foreign exchange banks in Indonesia, in 2013, had to increase their output variables such as total lending amounting to IDR133,858 (in millions) and net income of IDR182,308 (in millions).

While for 2014, foreign exchange banks in Indonesia had to reduce the value of inputs such as Total Deposits amounting to IDR3,421,690 (in millions), paid-up capital of IDR226,245 (in millions), and personal expenses of IDR132,970 (in millions). In 2014, the average foreign exchange bank in Indonesia had reached the optimum efficiency value in the credit component. However, the foreign exchange banks still have to increase the net profit output component by IDR66,967 (in millions) to achieve the optimal efficiency value.

Overall, foreign exchange banks in Indonesia are still experiencing a waste of input components throughout 2012-2014, so improvements in input components are needed in order to achieve optimal efficiency. In addition, foreign exchange banks also still have to increase their output components such as total lending and net income.

This study employs a regression analysis model with a Tobit model to test research hypotheses which aim to determine the relationship between the independent variable and the dependent variable.

The dependent variable is the bank's technical efficiency, and the independent variable consists of foreign bank ownership (FOREIGN) and the corporate governance mechanism proxied by the size of the board of commissioners (SUPVBOARD) and the size of independent commissioners (KI). In addition, this study uses control variables such as GOPUBLIC, NPL, and SIZE which are proxied by the total asset log. Regression results using Stata 13 are presented in Table 5.
Table 5. Results of Tobit Regression Analysis

\begin{tabular}{lcrr}
\hline Log Likelihood $=-4.774$ & & & \\
LR Chi2 $(6)=41.71$ & & & \\
Prob $>$ Chi2 $=0.000$ & & & \\
Pseudo R2 $=0.813$ & & & \\
\hline \multicolumn{1}{c}{ Variable } & Coefficient & T-Value & P-value \\
\hline FOREIGN & 0.062 & 1.85 & $0.066^{* *}$ \\
SUPVBOARD & 0.017 & 1.57 & 0.119 \\
KI & -0.171 & -2.40 & $0.018^{*}$ \\
GOPUBLIC & 0.033 & 0.94 & 0.350 \\
NPL & -0.777 & -0.86 & 0.391 \\
SIZE & 0.108 & 3.72 & $0.000^{*}$ \\
CONSTANT & 0.014 & 0.08 & 0.939 \\
\hline
\end{tabular}

*significant at 0.05

**significant at 0.1

Table 5 show bank ownership by foreign parties (FOREIGN) having a positive regression coefficient equals to 0.062. Statistically, bank ownership variable by foreign parties significantly affects the bank's technical efficiency because it has $p<0.1$ with $p$-value equals to 0.066 or significant at 0.1 . It can be concluded that the first hypothesis which states that the variable ownership of shares by foreigners has a positive effect on the technical efficiency of the bank is accepted.

The size of the board of commissioners (SUPVBOARD) has a regression coefficient of 0.017 and has $p>0.05$ which is equal to 0.119. Statistically, the size of the board of directors does not affect the bank's technical efficiency. Thus, the second hypothesis stating that the size of the board of directors has a positive effect on the bank's technical efficiency is rejected.

The variable size of KI has a negative regression coefficient of 0.171 and $p<0.05$ which is equal to 0.018 . Statistically, the size of the board of directors has a negative effect on the bank's technical efficiency. Thus, the second hypothesis stating that the size of independent commissioners has a positive effect on the bank's technical efficiency is rejected.

The variable of bank GOPUBLIC has a positive regression coefficient which is equal to 0.033 . 
Statistically, the bank's Go Public status variable is not significant because it has $p>0.05$. Hence this result shows that the status of public ownership is not related to the bank's efficiency.

The variable of NPL has a negative regression coefficient of 0.777 . Statistically, NPL variable does not affect technical efficiency because it has $\mathrm{p}$ $>5$ percent which is equal to 0.391 . These results do not affect the hypothesis because NPL variable only controls variables which complement the research model.

The bank SIZE has a positive regression coefficient of 0.108 . This bank size variable is statistically significant because it has $\mathrm{p}<0.05$ which shows that the size of the bank has a positive impact on the bank's efficiency. The bigger the bank, the higher the efficiency.

In regard to the goodness of fit, the likelihood ratio of chi-square equals to $41.71(\mathrm{df}=6)$ with $\mathrm{p}$-value 0.000 indicates that the model as a whole fits significantly. The pseudo $R^{2}$ is 0.813 which means that 81.3 percent variations of technical efficiency are explained by independent variables. As the pseudo R2 is more than 80 percent which is considered high, the model is accepted.

\section{DISCUSSION}

\section{The Effect of Bank Ownership by Foreign Parties on Banking Technical Efficiency}

The results of testing with Tobit regression indicate that bank ownership by foreign parties (FOREIGN) significantly has an influence on the level of bank technical efficiency, and the results of this test are consistent with the previous research studies (Delis \& Papanikolu 2009; Muazaroh et al., 2012).

The results of this study support the hypothesis of Genay et al. (2000) which describes Global Advantage Hypothesis where foreign institutions can operate more efficiently than domestic institutions because foreign institutions have excellent managerial and policy expertise in their fields. In addition, bank ownership by foreign parties has better risk management expertise and a better culture of corporate governance than that of local banks (Delis \& Papanikalou, 2009).

\section{The Effect of the Size of the Board of Commissioners on Banking Technical Efficiency}

Although the size of the existing board of commissioners will increase the power of management monitoring (Ghofar \& Islam, 2015). However, some previous researches (Lipton \& Lorsch, 1992; Jensen, 2010) assume that the larger size of the existing board of commissioners will create coordination and communication problems, resulting in poor performance of the company. In addition, the oversize board of commissioners will make the company spend more money to provide payment. However, this is not proportional to the decisions and supervision which is conducted because problems such as free riders will appear; meanwhile, the board of commissioners will tend to be passive and depend on their obligations to the other commissioners (Jensen, 2010). In addition, the greater the size of the board of commissioners can provide more problems, namely increasing Agency Cost (Jensen \& Meckling, 1976).

\section{The Effect of the Independent Commissioners on Banking Technical Efficiency}

Previous research conducted by Liu \& Lu (2007) in China shows that independent commissioners will provide the benefits of supervision in corporate governance and will have a positive impact on the company's efficiency performance. On the other hand, there has been a difference in the results of this study which revealed that there is a negative relationship between the size of independent commissioners and the bank's technical efficiency. This difference is likely due to differences in location and culture. 
In addition, the increase in the size of independent commissioners is only used to eliminate the regulatory provisions, leading to the supervision of management's efficiency and consumption performance not increasing. Liu \& Lu (2007) and strong supervision and the size of independent commissioners can be an obstacle because independent commissioners can withhold management to be more innovative in managing efficiency and adapting to changes in the business environment (Gani \& Jermias, 2006). According to Ghofar \& Islam (2015) the placement of independent board of directors in the Indonesian market is only intended for regulatory compliance without fully carrying out its role as management supervision.

\section{CONCLUSION AND SUGGESTIONS}

\section{Conclusion}

In the first stage analysis, it is known that the average foreign exchange bank in Indonesia is still not efficient, the inefficiencies in foreign exchange banks in Indonesia occur due to waste of inputs analyzed such as Third Party Funds (TPF), Paid-in Capital and Personnel Expenses so that outputs (Total Financing and the Net Profit) generated are not optimal. However, even though the average foreign exchange banks are considered not able to achieve optimal efficiency, there has been an improvement in efficiency from 2012-2013. This can reflect that the efficiency performance of foreign exchange banks in Indonesia as an intermediary institution increases from year to year. The second stage analysis test employs the Tobit regression model with the independent variables of bank ownership by foreign parties and the corporate governance mechanism which is proxied by the size of the board of commissioners and the size of the independent commissioner. The variable of bank ownership by foreign parties has a significant positive effect on the technical efficiency of foreign exchange banks in Indonesia. The corporate governance mechanism is proxied for the size of the board of commissioners and the percentage of the independent commissioners. The size of the board of commissioners does not have an effect on technical efficiency, while the size of independent commissioners has a negative influence on technical efficiency. The increase in the size of independent commissioners is only used to eliminate the regulatory provisions, which has led to an increase in supervision of management performance and consumption.

\section{Suggestions}

However, this study has a limitation which the use of input variables and output variables in DEA analysis is only based on previous research without more in-depth research whether input variables and output variables are used robustly in measuring the level of technical efficiency. The next research may extend the study by including more input and output factors to provide more in-depth factors of input and output which may influence the efficiency of banks. The comparison of other emerging countries banks should be considered also to increase the external validity of the study.

\section{REFERENCES}

Bank Indonesia. (2014). Statistik Perbankan Indonesia. http:// www.bi.go.id.

Berger, A. N., \& Mester, L. J. (1997). Inside the black box: What explains differences in the efficien- cies of financial institutions? Journal of Banking $\mathcal{E}$ Finance, 21(7), 895-947. https:/ / doi.org/10.1016/S03784266(97)00010-1

Berger, A. N., \& DeYoung, R. (1997). Problem loans and cost effi- ciency in commercial banks. Journal of Banking $\mathcal{E}$ Finance, 21(6), 849-870. https://doi.org /10.1016/S0378-4266(97) 00003-4

Bruce, D. N. (2011). Corporate governance mechanisms and firm 


\section{Foreign Ownership, Corporate Governance Mechanism and Technical Efficiency of Indonesia Banking Industry Abdul Ghofar \& Farisan Noviandry}

efficiency. International Journal of Business and Management, 6(5), 28-40. https://doi.org/10.5539/ ijbm.v6n5p28

Carcello, J. V., \& Neal, T. L. (2003). Audit committee independence and disclosure: Choice for financially distressed firms. Corporate Governance: An International Review, 11(4), 289-299. https://doi.org/10.1111/ 1467-8683.00327

Chen, J. J. (2005). China's institutional environment and corporate governance. Corporate Governance: A Global Perspective Advances in Financial Economics, 11, 75-93.

Claessens, S., Demirgüç-Kunt, A., \& Huizinga, H. (2001). How does foreign entry affect domestic banking markets? Journal of Banking \& Finance, 25(5), 891911. https://doi.org/10.1016/ S0378-4266(00)00102-3

Colley, J. L., Doyle, J. L., Logan, G. W., \& Stettinius, W. (2003). Corporate Governance: Business, Legal, $\mathcal{E}$ Ethical Challenges Faced by Boards of Directors, and Methods for the Selection, Performance Appraisal, Compensation, $\mathcal{E}$ Succession Planning for the CEO, and How to Maintain Effective Relationships with All Constituencies. New York: McGraw-Hill.

Delis, M. D., \& Papanikolaou, N. I. (2009). Determinants of bank efficiency: Evidence from a semi-parametric methodology. Managerial Finance, 35(3), 260275. https://doi.org/10.1108/ 03074350910931771

Drake, M. S., Myers, J. N., \& Myers, L. A. (2009). Disclosure quality and the mispricing of accruals and cash flow. Journal of Accounting, Auditing, E Finance,
24(3), 357-384. https://doi.org/ 10.1177/0148558X0902400303

Epstein, M. K., \& Henderson, J. C. (1989. Data envelopment analysis for managerial control and diagnosis. Decision Sciences: A Journal of the Decision Sciences Institute, 20(1), 90-119. https://doi.org/10.1111/ j.1540-5915.1989.tb01399.x

Farrell, M. J. (1957). The Measurement of productive efficiency. Journal of the Royal Statistical Society, 120(3), 253-290. https:// doi.org/10.2307/2343100

Gani, L., \& Jermias, J. (2006). Investigating the effect of board independence on performance across different strategies. The International Journal of Accounting, 41(3), 295-314. https:/ / doi.org/10.1016/j.intacc. 2006. 07.009

Gardener, E., Molyneux, P., \& Nguyen-Linh, H. (2011). Determinants of efficiency in South East Asian banking. The Service Industries Journal, 31(16), 26932719. https://doi.org/10.1080 /02642069.2010.512659

Genay, H., Udell, G. F., DeYoung, R., \& Berger, A. N. (2000). Globalization of financial institutions: Evidence from cross-border banking performance. BrookingsWharton Papers on Financial Services, 23-120. http://dx.doi. org/10.2139/ssrn.203509

Ghofar, A., \& Islam, S. M. (2014). Corporate Governance and Contingency Theory: A Structural Equation Modeling Approach and Accounting Risk Implications. New York: Springer.

Holod, D., \& Lewis, H. F. (2011). Resolving the deposit dilemma: A new DEA bank efficiency model. Journal of Banking $\mathcal{E}$ Finance, 35(11), 2801-2810. https: //doi.org/10.1016/j.jbankfin. 2011.03.007

Hoque, M. R. \& Rayhan, M. I. (2012). Data envelopment analyis of banking sector in Bangladesh. Russian Journal of Agricultural and Socio-Economic Sciences, 5(5), 17-22.

Jamali, H., Sutrisno, T., Subekti, I., \& Assih, P. (2015). The Influence of corporate governance and corporate social responsibility on financial performance with efficiency as mediating variable. International Journal of Business and Management Invention, 4(5), 1-10.

Jensen, M. C. (2010). The modern industrial revolution, exit, and the failure of internal control systems. Journal of Applied Corporate Finance, 22(1), 43-58. https://doi.org/10.1111/ j.1540-6261.1993.tb04022.x

Jensen, M. C., \& Meckling, W. H. (1976). Theory of the firm: Managerial behaviour, agency costs, and ownership structure. Journal of Financial Economics, 3(4), 305-360. https://doi.org/ 10.1016/0304-405X(76)90026$\mathrm{X}$

Kiel, G. C., \& Nicholson, G. J. (2003). Board composition and corporate governance: How the Australian experience informs contrasting theories of corporate governance. Corporate Governance: An International Review, 11(3), 189-205. https://doi.org/ 10.1111/1467-8683.00318

Kumbhaker, S. C., \& Lovell, C. A. K. (2000). Stochastic Frontier Analysis. Cambridge: Cambridge University Press. 
Larmou, S., \& Vafeas, N. (2010). The relation between board size and firm performance in firms with a history of poor operating performance. Journal of Management \& Governance, 14 (1), 61-85. https://doi.org/ 10.1007/s10997-009-9091-z

Lefort, F., \& Urzua, F. (2008). Board independence, firm performance, and ownership concentration: Evidence from Chile. Journal of Business Research, 61(6), 615-622. https:// doi.org /10.1016/j.jbusres.2007.06.036

Lipton, M., \& Lorsch, J. W. (1992). A modest proposal for improved corporate governance. The business lawyer, 48(1), 59-77. Retrieved from: http://www.jstor. org/stable/40687360

Liu, Q., \& Lu, Z. J. (2007). Corporate governance and earnings management in the Chinese listed companies: A tunneling perspective. Journal of Corporate Finance, 13(5), 881-906. https:/ /doi.org/10.1016/j.jcorpfin. 2007.07.003

Lu, W., Wang, W., Hung, S. \& Lu, E. (2012). The effects of corporate governance on airline performance: Production and marketing efficiency perspectives. Transportation Research, 48(2), 529-544. https:// doi.org/ 10.1016/j.tre.2011.09.003

Muazaroh, Eduardus, T., Husnan, S., \& Hanafi, M. M. (2012). Determinants of bank profit efficiency: Evidence from Indone- sia. International Journal of Economics and Finance Studies, 4(2), 163-173.

Mueller, D. C. (2006). Corporate governance and economic performance. International Review of Applied Economics, 20(5), 623643. https://doi.org/10.1080/ 02692170601005598

Otoritas Jasa Keuangan. (2015). Master plan sector jasa keuangan Indonesia. http:// www.ojk.go.id

Song, F., \& Thakor, A. V. (2015). Bank culture. Journal of Financial Intermediation, 1-51. https:// doi.org/10.1016/j.jfi.2018. 06. 005

Sathye, M. (2003). Efficiency of banks in a developing economy: The case of India. European Journal of Operational Research, 148(3), 662-671. https://doi.org/10. 1016/S0377-2217(02)00471-X

Sufian, F., \& Noor, M. A. N. M. (2009). The determinants of Islamic banks' efficiency changes: Empirical evidence from the MENA and Asian banking sectors. International Journal of Islamic and Middle Eastern Finance and Management, 2(2), 120-138. https://doi.org/ 10.1108/17538390910965149

Sufian, F., \& Habibullah, M. S. (2010). Developments in the efficiency of the Thailand banking sector: A DEA approach. International Journal of Development Issues, 9(3), 226-245. https:// doi.org/10.1108/14468951 011073316
Suryanto, T. (2016). Audit delay and its implication for fraudulent financial reporting: A study of companies listed in the Indonesian stock exchange. European Research Studies, 19(1), 1831.

Wang, K., Huang, W., Wu, J., \& Liu, Y. N. (2014). Efficiency measures of the Chinese commercial banking system using an additive two-stage DEA. Omega, 44, 5-20. https://doi.org/10.1016/ j.omega.2013.09.005

Ward, A. J., Brown, J. A., \& Rodriguez, D. (2009). Governance bundles, firm performance, and the substitutability and complementarity of governance mechanisms. Corporate Governance: An International Review, 17(5), 646660. https://doi.org/10.1111/ j.1467-8683.2009.00766.x

Williams, J., \& Nguyen, N. (2005). Financial liberalisation, crisis, and restructuring: A comparative study of bank performance and bank governance in South East Asia. Journal of Banking $\mathcal{E}$ Finance, 29(8), 2119-2154. https: //doi.org/10.1016/j.jbankfin. 2005.03.011

Yunos, R. M. (2011). The effect of ownership concentration, board of directors, audit committee, and ethnicity on conservative accounting: Malaysian evidence. Thesis. Faculty of Business and Law Edith Cowan University. 